\title{
Release of dissolved organic carbon and nitrogen by the zooxanthellate coral Galaxea fascicularis
}

\author{
C. Ferrier-Pagèss ${ }^{1, *}$, J.-P. Gattuso ${ }^{2}$, G. Cauwet ${ }^{3}$, J. Jaubert ${ }^{1}$, D. Allemand ${ }^{1}$ \\ ${ }^{1}$ Observatoire Océanologique Européen, Centre Scientifique de Monaco, Av. Saint-Martin, MC-98000, Monaco \\ ${ }^{2}$ Observatoire Océanologique, LOBEPM, UPRESA 7076, CNRS, BP 28, F-06234 Villefranche-sur-Mer cedex, France \\ ${ }^{3}$ Observatoire Océanologique, BP 44, F-66651 Banyuls-sur-Mer, France
}

\begin{abstract}
Corals are known to release large amounts of particulate and dissolved organic carbon (POC and DOC) and nitrogen (PON and DON). Production of POC and PON in the form of mucus has been relatively well studied, but very few data are available on the release of DOC and DON by corals. In order to investigate several aspects of carbon and nutrient cycling in corals, release of DOC and DON by fed and unfed colonies of the zooxanthellate coral Galaxea fascicularis (Linnaeus 1767) was measured in the laboratory under controlled conditions. Colonies were either fed with artemia or supplied with nitrogen- and phosphorus-enriched seawater. We measured DOC and DON fluxes from corals using the high temperature catalytic oxidation method and $\mathrm{DOC}$ release as ${ }^{14} \mathrm{C}$-photosynthate using a radioisotope technique. Corals released significant amounts of dissolved organic matter (DOM). Two large release peaks were observed in mid-morning and mid-afternoon. DOC concentrations increased from ca $100 \mu \mathrm{M}$ (background leve]) to $300-1700 \mu \mathrm{M}$, depending on the size of the colony and the trophic status. DON concentrations also increased from 15 to $120 \mu \mathrm{M}$. Release rates varied from

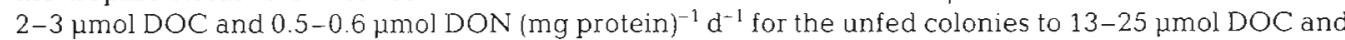
1-3 $\mu \mathrm{mol}$ DON (mg protein $)^{-1} \mathrm{~d}^{-1}$ for the artemia-fed colonies to $4-6 \mu \mathrm{mol} \mathrm{DOC}$ and $0.2-1.3 \mu \mathrm{mol}$ DON (mg protein) $)^{-1} d^{-1}$ for the nutrient-enriched colonies. Fed corals therefore released more DOC than unfed colonies, but tended to conserve organic nitrogen, suggesting that heterotrophic nutrition may serve corals as a source of new nutrients. Calculations of the carbon balance for the unfed colonies showed that DOC release represents ca $14 \%$ of the net daily photosynthetically fixed carbon. Following each peak in release, concentrations of DOM fell back to routine background levels. The role of free-living, epibiotic and/or intracellular bacteria in the uptake of DOM was therefore investigated. Colonies were labelled with ${ }^{14} \mathrm{C}$-bicarbonate and the subsequent release of ${ }^{14} \mathrm{C}$-DOM was followed in filtered seawater treated with and without prokaryotic inhibitors. No subsequent uptake of ${ }^{14} \mathrm{C}-\mathrm{DOM}$ was observed in the presence of inhibitors, suggesting that bacteria may play an important role in DOM uptake. This process may lead to tight nutrient recycling within coral colonies and may enable corals to thrive in oligotrophic waters.
\end{abstract}

KEY WORDS: Corals · Dissolved organic carbon and nitrogen $\cdot$ Release $\cdot$ Uptake

\section{INTRODUCTION}

Coral reef environments display a high gross primary production relative to the open ocean (Odum \& Odum 1955) and support a large variety of organisms. This high production has been explained by tight nutrient recycling within the reef ecosystem (Smith 1984). Corals are known to release large amounts of

\footnotetext{
•E-mail: ferrier@naxos.unice.fr
}

nutrients (Crossland 1987, Coffroth 1990) as particulate and dissolved organic carbon (POC and DOC) and nitrogen ( $\mathrm{PON}$ and DON). The POC and $\mathrm{PON}$ are generally referred to collectively as mucus. An important fraction (up to $40 \%$ ) of the photosynthetically fixed carbon translocated from the zooxanthellae to the coral host is released into the surrounding waters as mucus (Crossland et al. 1980, Edmunds \& Davies 1986, Crossland 1987), mucus sheets (Coffroth 1988, 1990) or flocs (Ducklow \& Mitchell 1979). Mucus varies greatly in biochemical composition (Ducklow \& Mitchell 1979 . 
Krupp 1985, Means \& Sigleo 1986, Crossland 1987, Meikle et al. 1988, Coffroth 1990) and trophic qualities (see Krupp 1985) depending on its age. Its composition can also be altered by the protocols used for its collection and subsequent analysis. Consequently, it has been described both as a material of low nutritional value for reef organisms (Krupp 1984, Meikle et al. 1988, Coffroth 1990) and as an important source of nutrients (Ducklow \& Mitchell 1979, Coffroth 1990, Sorokin 1993) and dissolved and particulate organic matter (DOM and POM).

While production of particulate or total organic matter in the form of mucus has been relatively well studied (Ducklow \& Mitchell 1979, Coffroth 1990, 1991), very few data are available on the release of DOC and DON (Crossland 1987, Bythell 1988, Yamamuro \& Kayanne 1997), despite DON representing more than $70 \%$ of the total dissolved nitrogen in coral reef waters (Crossland \& Barnes 1983, Johannes et al. 1983, Smith 1984) and dissolved compounds being more easily absorbed and more directly available to reef organisms. The above studies were performed in situ by enclosing a coral colony in a perspex chamber and measuring DOC and DON release after $1 \mathrm{~h}$ incubation or continously by collection on a filter. Crossland (1987) was one of the first to investigate release rates of mucus and DOC lipid in Acropora variabilis and Stylophora pistillata in different light regimes. He only measured the lipid compounds but found that DOC lipid represented a large fraction (75\%) of the total excreted organic carbon. Release rates were greatly influenced by light conditions and by the recent light history of corals, since these rates were higher for $5 \mathrm{~m}$ than for $10 \mathrm{~m}$ depth adapted colonies. Production of DON has only been investigated by Bythell (1988) and Yamamuro \& Kayanne (1997). Both observed that loss of nitrogen as DON was very important and could equal $50 \%$ of the total $\mathrm{N}$ requirement of the colony.

In order to gain a better understanding of the dynamics of DOM release and uptake in reef waters and hence a better estimation of its importance in the carbon and nitrogen cycles of coral reefs (Crossland et al. 1991), we estimated DOC and DON release by a zooxanthellate coral Galaxea fascicularis (Linnaeus 1767) over a 24 h cycle. Since DOM release partly depends on the coral nutritional status, 2 sets of experiments were performed in the laboratory, under controlled conditions, with both fed and unfed organisms. We measured total net DOC and DON fluxes from corals using the high temperature catalytic oxydation (HTCO) method as well as the net DOM release as ${ }^{14} \mathrm{C}$-photosynthate using a radioisotopic method. We also investigated the role of planktonic, epibiotic and/or intracellular bacteria in the subsequent uptake of this DOM.

\section{MATERIAL AND METHODS}

Coral preparation. Fourteen colonies of Galaxea fascicularis were prepared as described by Al-Moghrabi et al. (1993): terminal portions of branches were cut with bone cutters from parent colonies and suspended on nylon threads in aquaria illuminated with metal halide lamps (HQI, $400 \mathrm{~W}$ ). Constant irradiance of $200 \mu \mathrm{mol}$ photons $\mathrm{m}^{-2} \mathrm{~s}^{-1}$ was provided on a $12 \mathrm{~h}$ photoperiod. Aquaria were supplied with heated $\left(25^{\circ} \mathrm{C}\right)$ Mediterranean seawater. This water had low nutrient concentrations $(<0.3 \mu \mathrm{M}$ ammonium, $<1 \mu \mathrm{M}$ nitrate, $<0.1 \mu \mathrm{M}$ phosphorus) and chlorophyll a content $(0.2$ to $0.3 \mu \mathrm{g} \mathrm{C} \mathrm{l}^{-1}$ ), an aragonite saturation state of 3.1 to 3.7 (National Bureau of Standards; NBS), a pH of 8.1 to 8.2 and a dissolved inorganic carbon content of 2.3 to $2.4 \mathrm{mmol} \mathrm{kg}^{-1}$. After $1 \mathrm{mo}$, tissue had grown on the exposed skeleton, and coral fragments were entirely covered with new tissue. Colonies were then transferred to three $5 \mathrm{l}$ tanks and maintained under equivalent conditions of temperature and light.

In the first tank ('artemia fed'), 3 colonies were fed 3 times a week over $6 \mathrm{wk}$ with frozen adult Artemia sp. (Al-Moghrabi et al. 1993). Colonies were isolated for $3 \mathrm{~h}$ in three $5 \mathrm{I}$ beakers during feeding. In the tank, nutrient concentrations were measured every $3 \mathrm{~d}$ with an Alliance II autoanalyser following the method of Tréguer \& Le Corre (1975). Concentrations remained low during the experiment: $<0.2 \mu \mathrm{MN}-\mathrm{NH}_{4},<0.1 \mu \mathrm{M}$ $\mathrm{P}-\mathrm{PO}_{4},<0.2 \mu \mathrm{M} \mathrm{N}-\mathrm{NO}_{2}$ and 1 to $1.5 \mu \mathrm{MN}-\mathrm{NO}_{3}$.

In the second tank ('NP fed'), 3 colonies were maintained over $6 \mathrm{wk}$ in seawater enriched with inorganic nitrogen and phosphorus. Seawater and stock solutions of $\mathrm{NH}_{4} \mathrm{Cl}$ and $\mathrm{KH}_{2} \mathrm{PO}_{4}$ were continuously pumped into the tank with a peristaltic pump in order to obtain final concentrations of $1 \mu \mathrm{M} \mathrm{N}-\mathrm{NH}_{4}$ and $0.3 \mu \mathrm{MP}-\mathrm{PO}_{4}$. Nutrient concentrations were also measured every 3 to $4 \mathrm{~d}$ and were 0.9 to $1.2 \mu \mathrm{M} \mathrm{N}-\mathrm{NH}_{4}, 1$ to $1.5 \mu \mathrm{M} \mathrm{N}-\mathrm{NO}_{3}$, 0.3 to $0.5 \mu \mathrm{MP}-\mathrm{PO}_{4}$ and $<0.2 \mu \mathrm{M} \mathrm{N}-\mathrm{NO}_{2}$

In the third tank ('unfed'), 8 colonies were maintained over 6 wk in nutrient-poor Mediterranean seawater (concentrations were comparable to those measured in the 'artemia-fed' tank, $i$-test, $p<0.05$ ). Three colonies were used in the first experiment to compare their rates of DOM release with those of the fed colonies. The other 5 colonies were used in radioisotope experiments.

Measurements of DOC and DON fluxes using the HTCO method. Three colonies from each tank were incubated in three $2 \mathrm{l}$ beakers containing $0.22 \mu \mathrm{m}$ filtered seawater (FSW). Colonies were rinsed carefully with FSW to remove bacteria. Beakers were incubated in a thermoregulated bath $\left(26^{\circ} \mathrm{C}\right)$ illuminated with a metal halide lamp providing a constant irradiance of $200 \mu \mathrm{mol} \mathrm{m} \mathrm{m}^{-2} \mathrm{~s}^{-1}$ The medium was continu- 
ously aerated and mixed using a stirring bar. Colonies were incubated from 08:00 to $18: 00 \mathrm{~h}$, except for the 'artemia-fed' colonies, which were incubated over $24 \mathrm{~h}$. Seawater samples $(10 \mathrm{ml})$ were taken at intervals of 15 to $30 \mathrm{~min}$ for DOC, DON and DIN (dissolved inorganic nitrogen) measurements. Great care was taken to avoid touching the colonies during sampling. All glasses were acid-washed and combusted at $450^{\circ} \mathrm{C}$ for $4 \mathrm{~h}$.

Samples for DOC and DON measurements were filtered using Whatman GF/F filters in a glass filtration apparatus previously cleaned with a cold sulphuric acid and $\mathrm{K}_{2} \mathrm{Cr}_{2} \mathrm{O}_{7}$ mixture. The filters were precombusted at $450^{\circ} \mathrm{C}$ overnight prior to use. Filtrates were collected in $10 \mathrm{ml}$ precombusted glass tubes, closed with Teflon-backed screw caps, rinsed with MilliQ water and dried. They were treated with $100 \mu \mathrm{l}$ of a $1 \mathrm{~g}$ $\mathrm{l}^{-1} \mathrm{HgCl}_{2}$ solution and kept at $4^{\circ} \mathrm{C}$ pending analysis. Determination of DOC and total dissolved nitrogen (TDN) was performed by direct injection high temperature combustion (HTCO; Sugimura \& Suzuki 1988), using a Shimadzu TOC 5000 instrument fitted with $\mathrm{CO}_{2}$ (infrared) and $\mathrm{NO}$ (chemiluminescence) detectors (Sievers, NOA instrument). DON was calculated by subtraction of DIN from TDN. Samples were acidified with $100 \mu$ lof $1 \mathrm{M} \mathrm{HCl}$ and purged with clean air for $10 \mathrm{~min}$. The oxidation of organic compounds was carried out by injecting $100 \mu$ samples into a furnace at $680^{\circ} \mathrm{C}$ onto a catalyst made of $1.2 \%$ Pt-coated $\mathrm{SiO}_{2}$. The $\mathrm{CO}_{2}$ released was then measured using a nondispersive infra-red detector. Standard curves were constructed by injecting known amounts of potassium phthalate or nitrate (DON curves) dissolved in ultrapure, acidified and air-purged water. Data were corrected for blanks by injection of ultrapure water. The volume of incubation water decreased during the experiment as samples were regularly taken. The amount of DOC and DON release was therefore calculated by converting the concentrations to total amount of DOC and DON in the experimental beaker.

Rates of net photosynthesis and respiration were measured by a single colony in each tank over $24 \mathrm{~h}$. Colonies were incubated in a perspex chamber containing a polarographic oxygen sensor (Ponselle) immersed in a thermoregulated water bath $\left(25^{\circ} \mathrm{C}\right)$. The chamber was filled with FSW and stirred continuously with a magnetically coupled stirring bar. Light was provided by a 400 W (Philips, HPIT) metal halide lamp. The oxygen sensor was calibrated before each experiment against air-saturated seawater and a saturated solution of sodium dithionite (zero oxygen). Oxygen was recorded every minute using a Li-Cor LI-1000 datalogger. At the end of the experiments, colonies were frozen pending determination of the protein and chlorophyll a concentrations. Tissues were solubilized in $1 \mathrm{~N} \mathrm{NaOH}$ at $90^{\circ} \mathrm{C}$ for $30 \mathrm{~min}$, and the protein content was measured as described by
Lowry et al. (1951). The standard curve was established using bovine serum albumin as the standard, and absorbance was measured at $750 \mathrm{~nm}$ using an Alliance autoanalyser. Chlorophylls a and $c_{2}$ were extracted twice into $100 \%$ acetone $\left(24 \mathrm{~h}\right.$ at $\left.4^{\circ} \mathrm{C}\right)$. The extracts were centrifuged at $11000 \mathrm{rpm}(10000 \times \mathrm{g})$ for $10 \mathrm{~min}$, and the absorbances were measured at 630,663 and $750 \mathrm{~nm}$. Chlorophyll concentrations were computed according to the spectrophotometric equations of Jeffrey \& Humphrey (1975)

Organic carbon release with ${ }^{14} \mathrm{C}$-bicarbonate labelling. Radioisotope experiments were performed on 5 colonies of 'unfed' Galaxea fascicularis in order to confirm trends observed during the first set of experiments.

Three colonies were incubated over $12 \mathrm{~h}$ in 3 beakers containing $100 \mathrm{ml}$ of FSW and $100 \mu \mathrm{Ci}(0.37 \mathrm{GBq})$ of ${ }^{14} \mathrm{C}$-bicarbonate (total radioactivity: $2 \pm 0.1 \times 10^{8} \mathrm{dpm}$ ). Beakers were maintained at a constant temperature of $26^{\circ} \mathrm{C}$ and were illuminated with a metal halide lamp providing constant irradiance $\left(200 \mu \mathrm{mol} \mathrm{m} \mathrm{m}^{-2} \mathrm{~s}^{-1}\right)$. At the end of the incubation, total radioactivity was measured in the incubation medium $\left(0.7 \pm 0.3 \times 10^{8} \mathrm{dpm}\right)$. Colonies were carefully washed with FSW and kept overnight in an open-system aquarium. They were then transferred the next day to 3 beakers containing $100 \mathrm{ml}$ FSW. The release of labelled organic carbon into the incubation medium was investigated from $10: 00$ to $18: 00 \mathrm{~h}$; samples $(100 \mu \mathrm{l})$ were taken at intervals of 15 to $30 \mathrm{~min}$, acidified with $20 \mu \mathrm{l} 0.1 \mathrm{~N} \mathrm{HCl}$, and bubbled with nitrogen gas for $15 \mathrm{~min}$ in order to remove inorganic carbon. Radioactivity was measured immediately with a Packard Tri Carb 1600 CA scintillation counter. Due to the presence of radioactivity and to the small volume sampled $(100 \mu l)$, it was not possible to differentiate $\mathrm{DO}^{14} \mathrm{C}$ and $\mathrm{PO}^{14} \mathrm{C}$. However, in a preliminary experiment, large samples were drawn in order to assess the difference between filtered and non-filtered samples. Results showed that ca $90 \%$ of the newly excreted ${ }^{14} \mathrm{C}$-organic carbon was dissolved.

Role of bacteria in the removal of DOM released by corals. In order to investigate the uptake of DOC by free-living heterotrophic bacteria, $20 \mathrm{ml}$ of incubation medium was sampled from each beaker of the previous radioisotope experiment, following the maximum release of ${ }^{14} \mathrm{C}$. Samples were incubated separately for $5 \mathrm{~h}$. Sub-samples $(3 \mathrm{ml})$ were taken 3 times during the incubation, Millipore filtered $(0.22 \mu \mathrm{m})$ and counted for radioactivity. Concentrations of bacteria were determined in each beaker at the beginning and end of each incubation: $2 \mathrm{ml}$ samples were fixed using borax buffered formaldehyde ( $2 \% \mathrm{v}: \mathrm{v}$ final concentration) and stained with DAPI (4'6 diamidino-2-phenylindole; Porter \& Feig 1980). Bacteria were then filtered onto $0.22 \mu \mathrm{m}$ black Nuclepore ${ }^{\mathrm{TM}}$ filters and stored at $-20^{\circ} \mathrm{C}$. 
Organisms were counted at $\times 1000$ magnification under UV excitation with a Leica epifluorescence microscope.

The uptake of labelled organic carbon by epibiotic (Trench 1974) and/or intracellular bacteria was also investigated with 2 colonies of unfed Galaxea fascicularis, prepared as described above. Colonies were transferred the day after labelling to beakers contain-

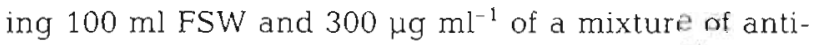
biotics (Sigma Co.) containing penicillin (104 units), streptomycin (10 mg) and amphotericin B $(25 \mu \mathrm{g})$. Preliminary experiments were performed on cultures of marine bacteria to determine the concentration of antibiotics needed to obtain a total inhibition of the bacterial growth. Results showed total inhibition of growth at a concentration of $100 \mu \mathrm{g} \mathrm{ml}^{-1}$. The release of labelled organic carbon in the incubation medium was investigated from 09:00 to 19:00 h. Radioactivity was measured immediately as described above.

Finally, the abundance of epibiotic and intracellular bacteria in the tissues of 2 small colonies of Galaxea fascicularis was investigated. Colonies were thoroughly washed with $0.22 \mu \mathrm{m}$ FSW; tissues were removed with a Waterpik and homogenized. Bacterial concentration was determined under epifluorescence microscopy after DAPI staining.

\section{RESULTS}

\section{DOC and DON release measured using the HTCO method}

Initial concentrations of DOC in the experimental water were low: 100 to $50 \mathrm{\mu mol}$ (Figs. 1, 2 \& 3). Similar diurnal patterns of DOC flux were observed under the
3 experimental conditions (fed and unfed organisms), with 1 or 2 important release events generally observed in mid-morning and mid-afternoon. The total amount of DOC released during each peak varied according to the experimental conditions and the size of the colony: 100 to $400 \mu \mathrm{mol}$ DOC for the 'unfed', 400 to $1700 \mu \mathrm{mol}$ DOC for the 'artemia-fed', and 250 to $400 \mu \mathrm{mol} D O C$ for the 'NP-fed' organisms (Figs. 1, 2 \& 3). The daily net release rates were ca 2.20 to $3.20 \mu \mathrm{mol}$ DOC (mg protein) $)^{-1} \mathrm{~d}^{-1}$ for 'unfed', 13 to $25 \mu \mathrm{mol}$ DOC (mg protein) ${ }^{-1}$ $\mathrm{d}^{-1}$ for 'artemia-fed' and 3.90 to $5.80 \mu \mathrm{mol}$ DOC (mg protein) ${ }^{-1} \mathrm{~d}^{-1}$ for 'NP-fed' organisms (Table 1). These rates were significantly different according to the coral nutritional status ( $t$-test, $\mathrm{p}<0.05$ ). Within $2 \mathrm{~h}$ following each peak, DOC concentration fell back to routine background levels (Figs. $1 \& 2$ ); for the 'NP-fed' colonies, a small quantity (50 to $100 \mu \mathrm{mol} C$ ) accumulated in the seawater (Fig. 3). No DOC release was observed during the nightime incubation for fed colonies (Fig. 4)

DON fluxes followed the same pattern as the DOC fluxes. The initial concentration was low: 10 to 15 umol. For the 'unfed' and 'artemia-fed' colonies, 1 or 2 release events were observed during the incubation, occurring approximately at the same time as the DOC release (Figs. 1 \& 2). Several DON releases occurred in the 'NP-fed' specimens (Fig. 3). The total amount of DON released during each peak varied according to the size of the colony and the experimental conditions: 15 to $70 \mu \mathrm{mol}$ for the 'unfed', 50 to $120 \mu \mathrm{mol}$ for the 'artemia fed', and 20 to $40 \mu \mathrm{mol}$ for the 'NP-fed' organisms. The daily release rates were 0.50 to $0.60 \mu \mathrm{mol}$ DON (mg protein) ${ }^{-1} \mathrm{~d}^{-1}$ for 'unfed', 1 to 3 umol DON (mg protein $)^{-1} \mathrm{~d}^{-1}$ for 'artemia-fed' and 0.20 to $1.30 \mu \mathrm{mol}$ DON (mg protein) $)^{-1} \mathrm{~d}^{-1}$ for 'NP-fed' organisms (Table 1). These rates were not significantly different $(t$-test, $p=$
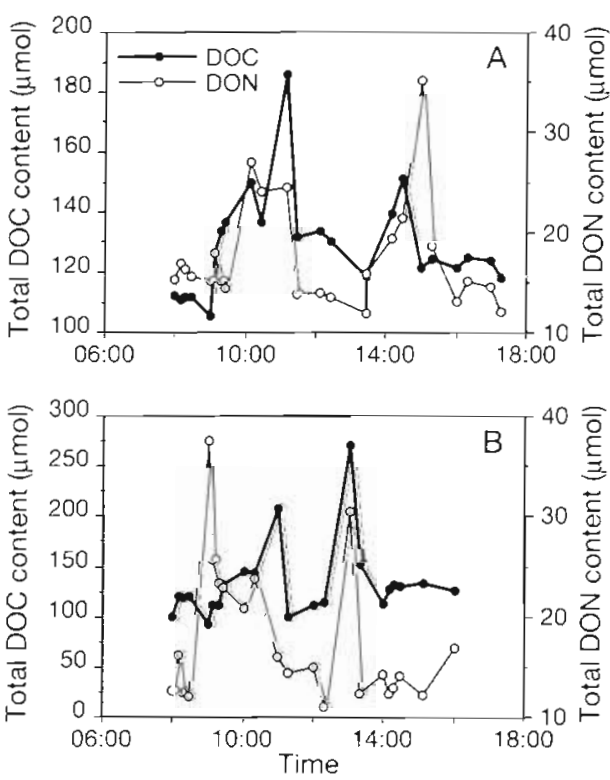
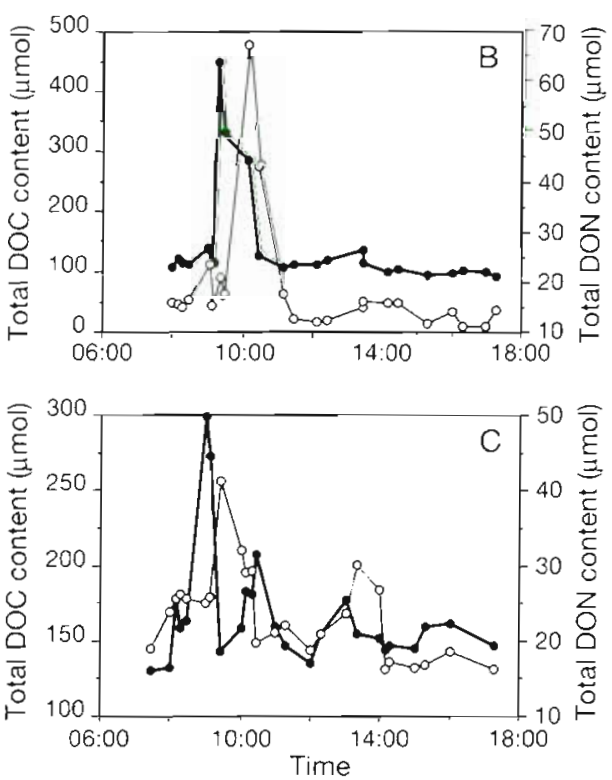

Fig. 1. Changes in total DOC and DON content in seawater during the incubation of 3 'unfed' colonies (referred to as $A, B$ and $C$ ). Two experiments were performed with colony $\mathrm{B}$ 

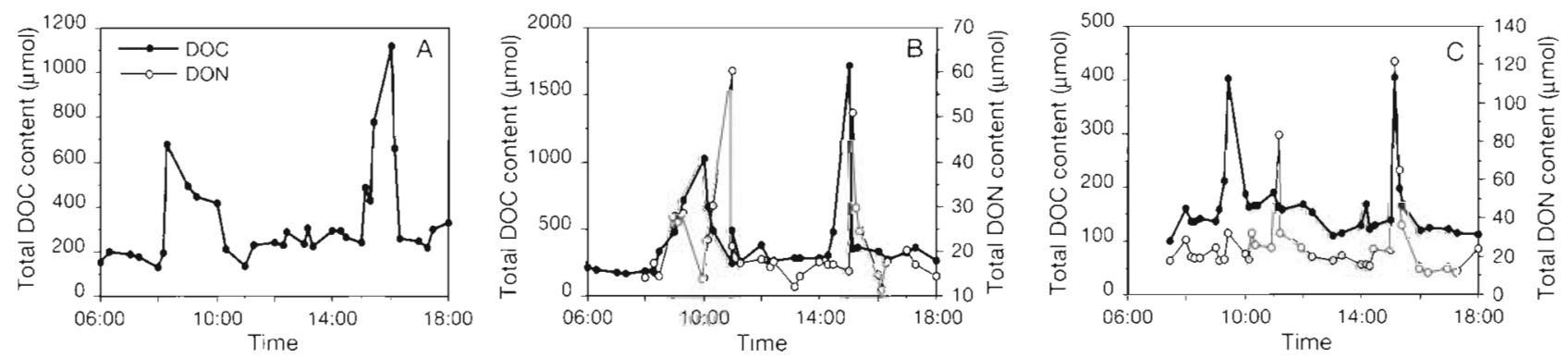

Fig. 2. Changes in total DOC and DON content in seawater durng the incubation of 3 'artemia-fed' colonies (referred to as A, B and C). DON determination was not performed with colony A
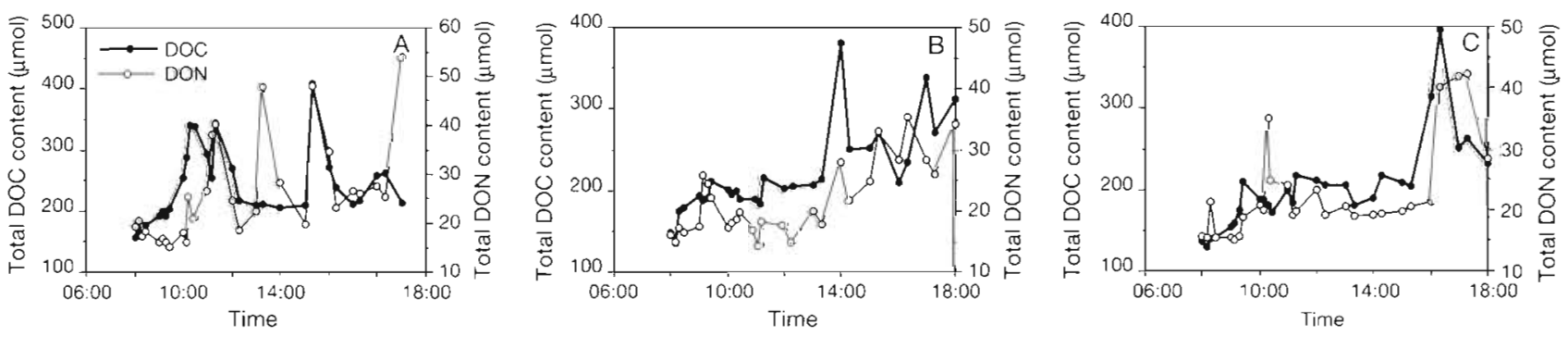

Fig. 3. Changes in total DOC and DON content in seawater during the incubation of 3 'NP-fed' colonies (referred to as A, B and C)

0.20 to 0.70 ). In a fashion similar to that of DOC, following each peak, DON concentration fell back to routine background levels. The C:N ratio of DOM was very low during the peak of release (between 2.5 and $4.5)$ in the 3 experiments but increased after the peak and varied from $2.5-4.5$ to $12-13$ during the whole experiment.

Inorganic nitrogen concentrations in the experimental beakers did not change significantly from the beginning to the end of the incubation $(p<0.05)$ Nutrient concentrations varied between 0 and $0.2 \mu \mathrm{M}$ for nitrite, 0.2 and $0.5 \mu \mathrm{M}$ for ammonium, and 0.4 and $0.7 \mu \mathrm{M}$ for nitrate. The rates of net photosynthesis and dark respiration were almost constant (Fig. 5). Net photosynthesis and dark respiration were, respectively, 0.45 to $0.52 \mu \mathrm{mol} \mathrm{O}_{2} \mathrm{~h}^{-1}$ (mg protein) $)^{-1}$ and 0.26 to $0.30 \mu \mathrm{mol} \mathrm{O} \mathrm{h}^{-1}$ (mg protein) $)^{-1}$. The total amount of carbon fixed varied between 291 and $355 \mu \mathrm{mol} \mathrm{C}$ (equal to 44 and $47 \mu \mathrm{g} \mathrm{C}$ [mg protein $\left.^{-1}\right]$ ).

\section{DOC release measured using ${ }^{14} \mathrm{HCO}_{3}$}

One or 2 peaks of ${ }^{14} \mathrm{C}$ organic matter release were observed during the incubation of the colonies in FSW (Fig. 6). The timing of these peaks was similar to that observed during the HTCO experiments. The total labelled carbon release produced $3-4 \times 10^{5} \mathrm{dpm}$. After the peak, the concentration decreased over 1 to $2 \mathrm{~h}$. No significant ${ }^{14} \mathrm{C}$ organic carbon uptake by freeliving bacteria was detected (Table 2). However, the concentration of bacteria was low (ca 4 to $7 \times 10^{3}$ bacteria $\mathrm{ml}^{-1}$ ), due to prior rinsing of corals and filtration of the medium $(0.22 \mu \mathrm{m})$.

The pattern of ${ }^{14} \mathrm{C}$ organic carbon release was different for colonies incubated in FSW containing antibiotics (Fig. 7). The organic carbon accumulated in the incubation medium, reached a plateau and remained stable for at least 3 to $5 \mathrm{~h}$. No decrease in the amount of

Table 1. Galaxea fascicularis. Protein and chlorophyll contents, dissolved organic carbon (DOC) release rates ( $\mu \mathrm{mol}$ DOC $[\mathrm{mg} \text { protein }]^{-1} \mathrm{~d}^{-1}$ ) and dissolved organic nitrogen (DON) release rates ( $\mu \mathrm{mol}$ DON [mg protein ${ }^{-1} \mathrm{~d}^{-1}$ ) for the studied colonies

\begin{tabular}{|c|c|c|c|c|c|}
\hline Expt & Colony & $\begin{array}{l}\text { Protein } \\
\text { (mg) }\end{array}$ & $\begin{array}{l}\text { Chlorophyll } \\
\text { (mg) }\end{array}$ & $\begin{array}{l}\mathrm{DOC} \\
\text { release rates }\end{array}$ & $\begin{array}{c}\text { DON } \\
\text { release rates }\end{array}$ \\
\hline $\begin{array}{l}\text { 'Unfed' } \\
\text { organisms }\end{array}$ & $\begin{array}{l}A \\
B \\
C\end{array}$ & $\begin{array}{l}74.8 \\
97.2 \\
58.8\end{array}$ & $\begin{array}{l}2.11 \\
2.04 \\
0.68\end{array}$ & $\begin{array}{l}2.20 \\
3.10 \\
3.20\end{array}$ & $\begin{array}{l}0.60 \\
0.60 \\
0.50\end{array}$ \\
\hline $\begin{array}{l}\text { 'Artemia-fed' } \\
\text { organisms }\end{array}$ & $\begin{array}{l}\mathrm{A} \\
\mathrm{B} \\
\mathrm{C}\end{array}$ & $\begin{array}{r}76.5 \\
106.9 \\
53.8\end{array}$ & $\begin{array}{l}2.02 \\
2.15 \\
0.65\end{array}$ & $\begin{array}{l}19.50 \\
24.50 \\
12.70\end{array}$ & $\begin{array}{c}- \\
1.20 \\
2.80\end{array}$ \\
\hline $\begin{array}{l}\text { 'NP-fed' } \\
\text { organisms }\end{array}$ & $\begin{array}{l}\mathrm{A} \\
\mathrm{B} \\
\mathrm{C}\end{array}$ & $\begin{array}{r}72.2 \\
101.5 \\
56.8\end{array}$ & $\begin{array}{l}1.98 \\
2.08 \\
0.65\end{array}$ & $\begin{array}{l}5.26 \\
5.80 \\
3.90\end{array}$ & $\begin{array}{l}1.30 \\
0.20 \\
0.60\end{array}$ \\
\hline
\end{tabular}




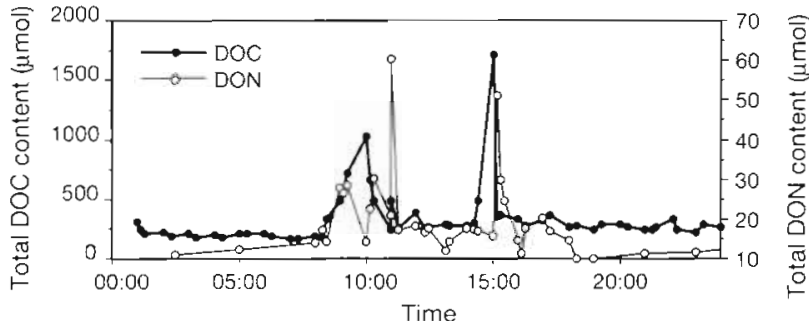

Fig. 4. Changes in total DOC and DON content in seawater during a $24 \mathrm{~h}$ experiment. Best example of the trends observed ('artemia-fed' colony)

${ }^{14} \mathrm{C}$ could be observed. The abundance of bacteria in the tissues of Galaxea fascicularis was equal to $4 \times 10^{9}$ bacteria for 3 polyps; this corresponds to $8.2 \times 10^{8}$ bacteria (mg tissue protein $)^{-1}$.

\section{DISCUSSION}

Results obtained in this study using 2 different techniques (HTCO and radiolabelling of photosynthates) confirm that scleractinian corals may be important producers of dissolved organic carbon and nitrogen. Production of DOM can be an important contribution to reef trophodynamics as it constitutes a direct input of nutrients (especially nitrogen) to the reef detrital pool.

The release of DOM from 'unfed' corals is likely to be a by-product of phototrophic nutrition (Muscatine et al. 1984) and could be controlled by the host. Muscatine et al. (1972) indeed showed that a host factor stimulates the excretion of organic compounds by zooxanthellae in vitro. We still have no explanation for the timing of DOM release; it does not seem to be due to diurnal changes in zooxanthellar photosynthetic activity, which remained nearly constant during the day (Fig. 5). Similarly, no differences in respiration rate were found at night. Crossland (1987) observed that in situ release of mucus was maximal in the afternoon. He suggested that this pattern could reflect preferential utilization of energy and carbon from photosynthesis in the morning to replenish tissue carbon reserves used during the night. However, this afternoon maximum for mucus

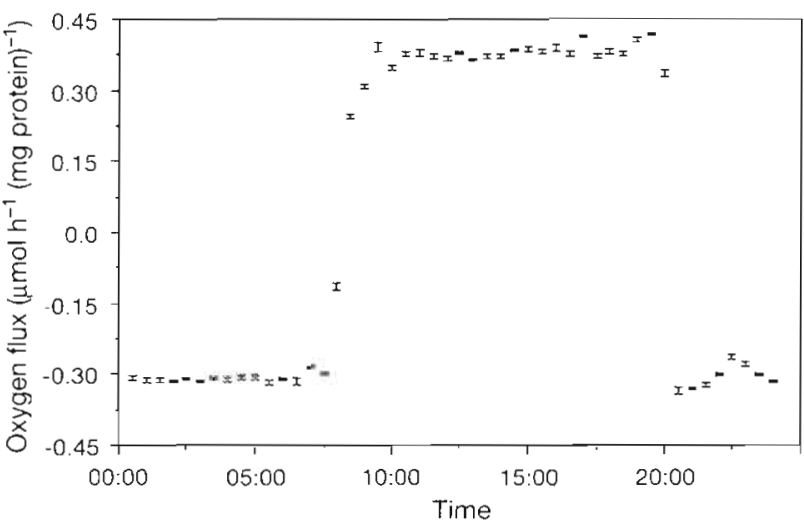

Fig. 5. Oxygen flux during a 24 h experiment. Best example of the trend observed

production was also observed in corals adapted to shade conditions, even if the daily net photosynthesis was reduced and thus the surplus organic carbon. The relation between light, photosynthesis and mucus/ DOC production remains be investigated in future studies.

DOM release appears to be significantly enhanced by heterotrophic feeding as 'artemia-fed' colonies released 2 to 3 times more DOC than the 'unfed' colonies. The first step in digestion in coelenterates is extracellular, whereby particulate food is decomposed in the gastric cavity. According to Schlichter (1982a, b), DOM liberated by this process in the coelenteron is excreted to the external seawater. Although fed corals released more DOC than unfed colonies, they tended to conserve organic nitrogen, which was excreted in the same amount irrespective of the feeding status. This suggests that heterotrophic nutrition may serve corals as a source of new nutrients, supplying nitrogen, phosphorus or vitamins (Dubinsky \& Jokiel 1994), while carbon obtained through this pathway is subsequently released. In this case, there could also be a reverse translocation of these new nutrients from coral to algae (D'Elia \& Cook 1988). Bythell (1988), who examined the carbon and nitrogen budget of the coral Acropora palmata, suggested that $70 \%$ of the nitrogen requirement was met by host particulate feeding, compared to

Table 2. Amount of ${ }^{14} \mathrm{C}$ organic matter and bactenal concentration in beakers containing the coral incubation medium and the associated bacteria. Data represent mean and standard deviation of 3 samples

\begin{tabular}{|c|c|c|c|}
\hline Concentration & Beaker 1 & Beaker 2 & Beaker 3 \\
\hline Amount of radioactivity at the beginning $\left(\times 10^{3} \mathrm{dpm}\right)$ & $475 \pm 20$ & $290 \pm 11$ & $380 \pm 5$ \\
\hline Amount of radioactivity after $2 \mathrm{~h}$ incubation $\left(\times 10^{3} \mathrm{dpm}\right)$ & $470 \pm 15$ & $295 \pm 20$ & $390 \pm 10$ \\
\hline Amount of radioactivity after $5 \mathrm{~h}$ incubation $\left(\times 10^{3} \mathrm{dpm}\right)$ & $490 \pm 10$ & $280 \pm 10$ & $390 \pm 30$ \\
\hline 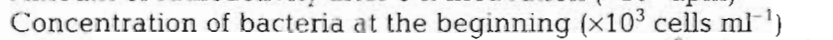 & $4.0 \pm 0.2$ & $7.1 \pm 0.3$ & $4.5 \pm 0.1$ \\
\hline Concentration of bacteria after $5 \mathrm{~h}$ incubation $\left(\times 10^{3}\right.$ cells $\left.\mathrm{ml}^{-1}\right)$ & $4.1 \pm 0.2$ & $7.2 \pm 0.2$ & $4.8 \pm 0.5$ \\
\hline
\end{tabular}



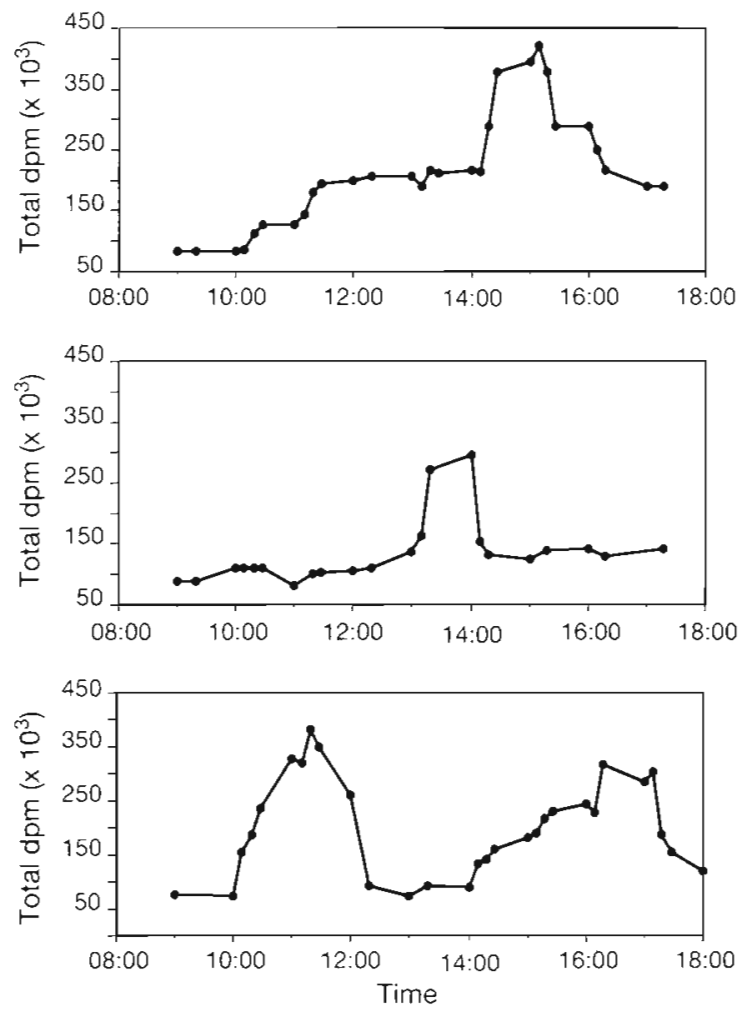

Fig. 6. Variations in the amount of ${ }^{14} \mathrm{C}$-labelled organic carbon in seawater during a diurnal incubation of 3 different 'unfed' colonies

$9 \%$ for carbon. The 'NP-fed' colonies also did not excrete significantly more DON than the 'unfed' colonies. Means \& Sigleo (1986) observed that the in situ excretion of colloidal nitrogen $\left(0.4 \mu \mathrm{mol} \mathrm{l}^{-1} \mathrm{~d}^{-1}\right)$ was 2 orders of magnitude lower than the excretion of colloidal carbon $\left(21 \mu \mathrm{mol} \mathrm{l^{-1 }} \mathrm{d}^{-1}\right)$. Nitrogen retention could be an indication that zooxanthellae are nitrogen limited (Muscatine et al. 1989) and tend to conserve this nutrient when available. Despite the relatively low excretion of DON (compared to DOC), it can represent the most abundant dissolved nitrogen form in nutrientimpoverished reef waters.

Calculation of the carbon balance for the 'unfed' Galaxea fascicularis shows that DOC release (200 to $400 \mu \mathrm{mol}$ ) accounts for ca 11 to $14 \%$ of the daily photosynthetically fixed carbon, as estimated from productivity (3.4 to $4.2 \mathrm{mg} \mathrm{C}$ ). This is in agreement with other estimates of DOC release (Crossland 1987, Sorokin 1993). Crossland (1987) estimated that 8 and 10 to $21 \%$ of the net photosynthetically fixed carbon is lost as DOC in the scleractinian corals Acropora acuminata and Stylophora pistillata, respectively. Sorokin (1993) calculated that DOC excretion accounts for 20 to $25 \%$ of the rate of photosynthetically fixed carbon in several coral species. These release rates approximate those found for phytoplankton by Baines \& Pace (1991).
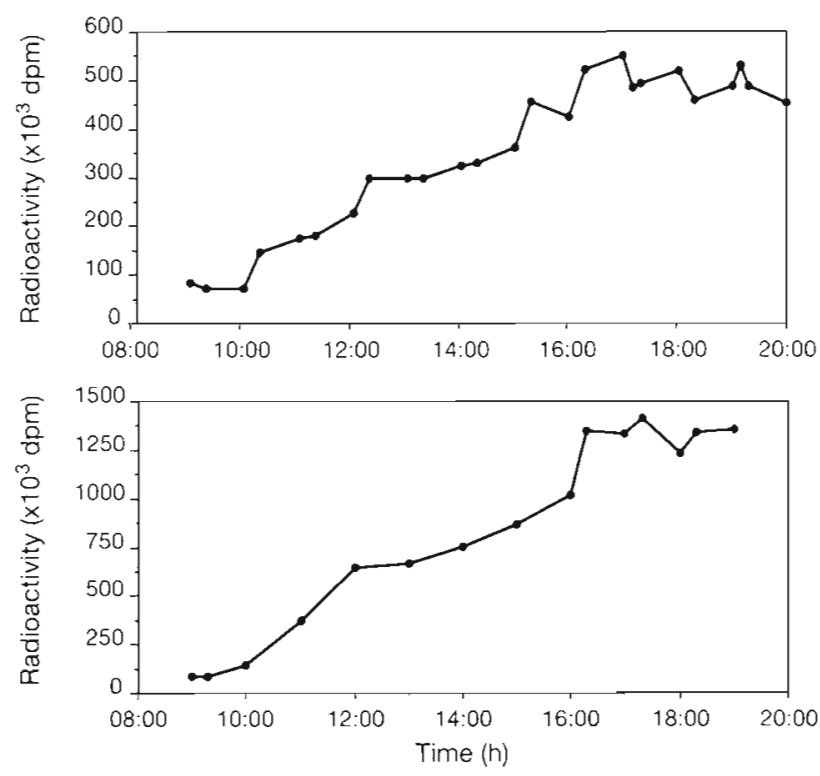

Fig. 7. Variations in the amount of ${ }^{14} \mathrm{C}$-labelled organic carbon in seawater during a diurnal incubation of 2 'unfed' colonies with an antibiotic mixture

These authors reported, in a study based on 225 observations, that extracellular DOC release was equal to $13 \%$ of total carbon fixation.

In this experiment, a decrease in DOM concentrations was observed over a period of $2 \mathrm{~h}$ of its release by corals. This decrease could not be attributed to uptake by free-living bacteria, which were present in very low concentrations in the incubation medium. Data on DOC consumption by free-living bacterioplankton have shown removal rates of 0.04 to $0.8 \mu \mathrm{mol} \mathrm{C} \mathrm{l}^{-1} \mathrm{~h}^{-1}$ (Carlson \& Ducklow 1996, Zweifel et al. 1996). These rates were obtained with high bacterial concentrations $\left(\geq 10^{6}\right.$ bacteria $\mathrm{ml}^{-1}$ ). Therefore, in our experiments, removal of DOM cannot be explained by the activity of the planktonic bacteria since 200 to $500 \mu \mathrm{mol}$ DOC (or 250 to $600 \mu \mathrm{M} \mathrm{C}$ ) or even more disappeared within $2 \mathrm{~h}$ (according to the estimated maximal removal rate, only 4 umol would have been removed by bacteria).

A second hypothesis to explain DOM removal from the incubation medium is the spontaneous assembly of DOC into polymer gels (Chin et al. 1998). This process can start after 30 min of incubation, and the formation of microgels continues for the next $50 \mathrm{~h}$, reaching an equilibrium after this. Therefore, DOM polymers can undergo rapid spontaneous assembly into POM particles. However, this was not the case in our experiments because, in the radioisotope experiments with the antibiotic mixture, there was no subsequent decrease in organic ${ }^{14} \mathrm{C}$ after its release.

A third and final explanation could be uptake by epibiotic and/or intracellular bacteria. Trench (1974) 
demonstrated that these bacteria can interfere with studies on uptake of DOM by corals. According to the results obtained in the incubations with antibiotics, the release of ${ }^{14} \mathrm{C}$ organic matter was not followed by a subsequent uptake, suggesting that the epibiotic or intracellular bacteria are the main organisms responsible for the disappearance of DOC in our experiments. We can therefore assume that a bacteria-coral association may have existed during our experiments, since a large amount of bacteria was found in the coral tissues. Several symbioses between marine animals and bacteria have been described, especially between bacteria and echinoderms (Kelly \& McKenzie 1995), bivalves (Krueger et al. 1996), sponges (Vacelet et al. 1995), clams (Southward 1990), brittle stars (Lesser \& Blakemore 1990) and sea anemones (Palincsar et al. 1989). Few studies have investigated the association between bacteria and corals, and of these most were conducted during diseases (Peters et al. 1983, Ritchie \& Smith 1995). However, high bacterial activity has been demonstrated in the coral surface mucopolysaccharide layers (Ducklow \& Mitchell 1979, Herndl \& Velimirov 1986, Paul et al. 1986).

This study demonstrates the apparently important role of bacteria in the regulation of DOM fluxes in corals. They are able to quickly take up DOM previously released and to transform it into bacterial biomass. These bacteria can be in turn a food source for corals (Sorokin 1993) or can use DOM for their own nutritional requirements and transfer other essential nutrients such as amino acids to their host. Schlichter $(1982 \mathrm{a}, \mathrm{b})$ demonstrated in the soft coral Heteroxenia fucescens that photosynthates produced by zooxanthellae in the gastrodermis are released to the coelenteron, washed out from the coelenteron into the surrounding seawater and 'recaptured' by the epidermis. Therefore, photosynthates potentially lost from the symbiotic system can be re-absorbed quickly by the epidermal parts of the colony. This release-uptake described by Schlichter (1982a, b) could have been due to epibiotic bacteria. In our experiments, after each release event, DOM concentrations fell back to routine background levels $(c d 100 \mu \mathrm{M}$ ), with no further bacterial uptake at this concentration. This may be explained by a different composition between DOM released by corals, which may be mostly 'labile', and DOM present in the jncubation medium, of a more 'refractory' nature. One of the next steps in this study will be to characterize the composition of the newly released DOM.

The amounts of DOM measured in this experiment are likely to be underestimated since DOM can be used by bacteria as soon as it is released. Comparison. of the results of Figs. $6 \& 7$ shows that DOM concentration increased regularly during the whole experiment with antibiotics whereas only 1 or 2 peaks could be measured under normal conditions. Corals could therefore release small amounts of DOM at all times, which would be taken up immediately by bacteria. except during massive release. In this case, bacteria seem to be saturated and to require more time to process all the DOM. In the field, a large fraction of the released DOC and DON may not remain available to corals due to the high flow rates over the reef flat which remove mucus and DOM from the waters adjacent to corals (Patterson et al. 1991). Therefore, DOM can be transferred to other reef organisms (Ducklow \& Mitchell 1979, Gotfried \& Roman 1983, Herndl \& Velimirov 1986) and may constitute an important source of organic matter export from the reef bottom organisms to the water column. Bacteria, for instance, are known to efficiently use the organic matter released by corals. Colony-forming bacteria are usually found in coral mucus and may play an important role in the mobilization of this mucus for consumption by other organisms (Ducklow \& Mitchell 1979). Moriarty \& Hansen (1990) also suggested that heterotrophic bacteria present on hard calcareous substrates utilize DOM released during photosynthesis by corals. During the peak of DON excretion, the C:N ratio of the DOM was very low (5:2) compared to the Redfield ratio for marine plankton $(106: 16)$. DOM is therefore a high quality food at that time and may sustain the high bacterial growth and production rates often reported in coral reef waters (Moriarty et al. 1985, Ducklow 1990, Sorokin 1993). The range of $\mathrm{C}: \mathrm{N}$ ratios obtained in this study (2.5 to 13 ) is close to that reported for mucous aggregates excreted by other coral colonies ( 7.4 to 44 ; Krupp 1984, Coffroth 1990). The rapid uptake of freshly excreted DOM may explain the low and relatively constant concentrations that have been measured in natural reef environments (Pagès et al. 1997) and the low DOM concentrations measured in reef waters relative to the open ocean (Suzuki et al. 1995).

Dissolved organic carbon in the oceans is one of the largest pools of reduced carbon on earth, yet little is known about its composition (Williams \& Druffel 1987), transformation, fluxes, or absolute concentration (Sharp 1993). There is also a general lack of quantitative information on both the production and the fate of the DON pool (Hopkinson 1993). Our results confirm previous observations that scleractinian corals can release a significant proportion of their photosynthetically fixed carbon as DOC. DON is also excreted, albeit at a lower rate than DOC. This is one of the first studies estimating the amount of DOM that corals are able to release in seawater in relation to their nutritional status. High rates of DOM release occur at specific times of the day. The mechanisms responsible for this timing are unknown and thus it is impossible to extrap- 
olate these results to the field. Finally, this study shows the important role of epibiotic and/or intracellular bacteria in the uptake of the released DOM. This can lead to a tight recycling of inorganic nutrients inside coral colonies, which is often described as a key process enabling coral reef ecosystems to thrive in oligotrophic waters (Smith 1984).

Acknowledgements. This study was partly supported by grants from Programme National Recifs Coralliens (PNRCOCNRS-ORSTOM). Thanks are due to Dr J. Chisholm and 3 anonymous referees for reviewing an earlier version of the manuscript. Contribution of PNRCO.

\section{LITERATURE CITED}

Al-Moghrabi S, Allemand D, Jaubert J (1993) Valine uptake by the scleractinian coral Galaxea fascicularis: characterization and effect of light and nutritional status. J Comp Physiol B 163:355-362

Baines SB, Pace ML (1991) The production of dissolved organic matter by phytoplankton and its importance to bacteria: patterns across marine and freshwater systems. Limnol Oceanogr 36:1078-1090

Bythell JC (1988) A total nitrogen and carbon budget for the elkhorn coral Acropora palmata. Proc 6th Int Coral Reef Symp 2:535-540

Carlson CA, Ducklow HW (1996) Growth of bacterıoplankton and consumption of dissolved organic carbon in the Sargasso Sea. Aquat Microb Ecol 10:69-85

Chin W, Orellana MV, Verdugo P (1998) Spontaneous assembly of marine dissolved organic matter into polymer gels. Nature 391:568-571

Coffroth MA (1988) The function and fate of mucus sheets produced by reef coelenterates. Proc 6th Int Coral Reef Symp 2:15-20

Coffroth MA (1990) Mucus sheet formation on poritid corals: an evaluation of coral mucus as a nutrient source on reefs. Mar Biol 105:39-49

Coffroth MA (1991) Cyclical mucous sheet formation on poritid corals in the San Blas Islands, Panama. Mar Biol 109:35-91

Crossland CJ (1987) In situ release of mucus and DOC-lipid from the corals Acropora variabilis and Stylophora pistilJata. Coral Reefs 6:35-42

Crossland CJ. Barnes DJ (1983) Dissolved nutrients and organic particulates in water flowing over coral reefs at Lizard Island. Aust J Mar Freshwat Res 34:835-844

Crossland CJ, Barnes DJ, Borowitzka MA (1980) Diurnal lipid and mucus production in the staghorn coral Acropora acuminata. Mar Biol 60:81-90

Crossland CJ, Hatcher BG. Smith SV (1991) Role of coral reefs in global ocean production. Coral Reefs 10:55-64

D'Elia CF, Cook CB (1988) Methylamine uptake by zooxanthellae-invertebrate symbioses: insights into host ammonium environment and nutrition. Limnol Oceanogr 33: $1153-1165$

Dubinsky Z, Jokiel P (1994) The ratio of energy and nutrient fluxes regulates the symbiosis between zooxanthellae and corals. Pac Sci 48:313-324

Ducklow HW (1990) The biomass, production and fate of bacteria in coral reefs. In: Dubinski Z (ed) Coral reefs. Ecosystems of the world, Vol 25. Elsevier, Amsterdam, p 265-289
Ducklow HW, Mitchel] R (1979) Composition of mucus released by coral reef coelenterates. Limnol Oceanogr 24 $706-714$

Edmunds PG. Davies PS (1986) An energy budget for Porites porites (Scleractinia). Mar Biol 92:339-347

Gottfried M, Roman MR (1983) Ingestion and incorporation of coral-mucus detritus by reef zooplankton. Mar Biol 72 $211-218$

Herndl GJ, Velimirov B (1986) Microheterotrophic utilization of mucus released by the Mediterranean coral Cladocora cespitosa. Mar Biol 90:363-369

Hopkinson C (1993) DON subgroup report. Mar Chem 41 : 23-36

Jeffrey SW, Humphrey JF (1975) New spectrophotometric equations for determining chlorophyll $a, b, c_{1}$ and $c_{2}$ in higher plants, algae and natural phytoplankton. Biochem Physiol Pflanzen 167:191-194

Johannes RE, Wiebe WJ, Crossland CJ (1983) Three patterns of nutrient flux in a coral reef community. Mar Ecol Prog Ser 12:131-136

Kelly MS, McKenzie JD (1995) Survey of the occurrence and morphology of sub-cuticular bacteria in shelf echinoderms from the north-east Atlantic Ocean. Mar Biol 123:741-756

Krueger DM, Gustafson RG, Cavanaugh CM (1996) Vertical transmission of chemoautotrophic symbionts in the bivalve Solemya velum (Bivalvia: Protobranchia). Biol Bull Mar Biol Lab Woods Hole 190:195-202

Krupp DA (1984) Mucus production by corals exposed during an extreme low tide. Pac Sci 38:1-11

Krupp DA (1985) An immunochemical study of the mucus from the solitary coral Fungia scutaria. Bull Mar Sci 36: $163-176$

Lesser MP, Blakemore RP (1990) Description of a novel symbiotic bacterium from the brittle star Amphipholis squamata. Appl Environ Microbiol 56:2436-2440

Lowry OH, Rosenbrough NJ, Farr AL, Randall RJ (1951) Protein measurement with the folin phenol reagent. J Biol Chem 193:265-275

Means JC, Sigleo AC (1986) Contribution of coral reef mucus to the colloidal organic pool in the vicinity of Discovery Bay, Jamaica. W I Bull Mar Sci 39:110-118

Meikle P, Richards GN, Yellowlees D (1988) Structural investigations on the mucus from six species of coral. Mar Biol 99:187-193

Moriarty DJW, Hansen JA (1990) Productivity and growth rates of coral reef bacteria on hard calcareous substrates and in sandy sediments in summer. Aust J Mar Freshwat Res 41:785-794

Moriarty DJW, Pollard PC, Hunt WG (1985) Temporal and spatial variation in bactenal production in the water column over a coral reef. Mar Biol 85:285-292

Muscatine L, Falkowski PG, Dubinsky Z, Cook PA, MCCloskey LR (1989) The effect of external nutrient resources on the population dynamics of zooxanthellae in a reef coral. Proc R Soc Lond Ser B 236:311-324

Muscatine L, Falkowski PG, Porter JW, Dubinsky Z (1984) Fate of photosynthetic fixed carbon in light-and shadeadapted colonies of the symbiotic coral Stylophora pistillata. Proc R Soc Lond Ser B 222:181-202

Muscatine L, Pool RR, Cernichiari E (1972) Some factors influencing selective release of soluble organic material by zooxanthellae from reef corals. Mar Biol 13:298-308

Odum HT, Odum EO (1955) Trophic structure and productivity of a windward coral reef community on Eniwetok atoll. Ecol Monogr 25:291-320

Pagès J, Torréton JP, Sempéré R (1997) Dissolved organic carbon in coral-reef lagoons, by high temperature catalytic 
oxidation and UV spectrometry. CR Acad Sci 324:915-922

Palincsar EE, Jones WR, Palincsar JS, Glogowski MA, Mastro JL (1989) Bacterial aggregates within the epidermis of the sea anemone Aiptasia pallida. Biol Bull Mar Biol Lab Woods Hole 177:130-140

Patterson MR, Sebens KP, Olson RR (1991) In situ measurements of flow effects on primary production and dark respiration in reef corals. Limnol Oceanogr 36:936-948

Paul JH, Deflaun MF, Jeffrey WH (1986) Elevated levels of microbial activity in the coral surface microlayer. Mar Ecol Prog Ser 33:29-40

Peters EC, Oprandy JJ, Yevich PP (1983) Possible cause of 'white band disease' in Carribean corals. J Invertebr Pathol 41:394-396

Porter KG, Feig YS (1980) The use of DAPI for identifying and counting aquatic microflora. Limnol Oceanogr 25:943-948

Ritchie KB, Smith GW (1995) Carbon-source utilization patterns of coral-associated marine heterotrophs. J Mar Biotechnol 3:105-107

Schlichter D (1982a) Epidermal nutrition of the alcyonarian Heteroxenia fuscescens (Ehrb.): absorption of dissolved organic material and lost endogenous photosynthates. Oecologia 53:40-49

Schlichter D (1982b) Nutritional strategies of the alcyonarian Heteroxenia fuscescens (Ehrb.): absorption of dissolved organic material and lost endogenous photosynthate. Oecologia 53:40-49

Sharp J (1993) The dissolved organic carbon controversy: an update. Oceanography 6:45-50

Smith SV (1984) Phosphorus versus nitrogen limitation in the marine environment. Limnol Oceanogr 29:1149-1160

Editorial responsibility: Otto Kinne (Editor),

Oldendorf/Luhe, Germany
Sorokin YI (ed) (1993) Coral reef ecology, ecological studies 102. Springer-Verlag, Berlin

Southward AJ (1990) Effect of temperature on autotrophic enzyme activity of bacteria symbiotic in clams and tube worms. Kieler Meeresforsch Sonderh 8:245-251

Sugimura V, Suzuki $Y(1988)$ A high-temperature catalytic oxıdation method for determination of non-volatile dissolved organic carbon in seawater by direct injection of liquid sample. Mar Chem 24:105-131

Suzuki Y, Nakashima N, Yoshida K, Casareto B, Taki M, Hiraga T, Okabayash. T, Ito $H$, Yamada K (1995) The important role of organic matter cycling for the biological fixation of $\mathrm{CO}_{2}$ in coral reefs. Energy Convers Manage $36: 737-740$

Tréguer P, Le Corre P (1975) Manuel d'analyse des sels nutritifs dans l'eau de mer (utilisation de l'Autoanalyseur II Technicon), 2nd edn. Lab d'Océanographie Chim Univ Bretagne Occidentale, Brest

Trench RK (1974) Nutritionnal potentials in Zoanthus sociatus. Helgol Wiss Meeresunters 26:174-216

Vacelet J, Boury-Esnault N, Fiala-Medioni A, Fisher CR (1995) A methanotrophic carnivorous sponge. Nature 377:296

Williams PM, Druffel M (1987) Radiocarbon in dissolved organic matter in the central North Pacific Ocean. Nature $330: 246-248$

Yamamuro M, Kayanne $H$ (1997) Dissolved organic nitrogen flux from coral colonies and calcareous sandy sediment. Galaxea 13:197-205

Zweifel UL, Blackburn N, Hagström A (1996) Cycling of marine dissolved organic matter. I. An experimental system. Aquat Microb Ecol 11:65-77

Submitted: March 25, 1998; Accepted: July 20, 1998

Proofs received from author(s): October 6, 1998 